\title{
Linking Transparency and Accountability to Local Legislative Performance in the Province of Nueva Ecija in the Philippines
}

\author{
Darwin U. Ong \& Arneil G. Gabriel (Corresponding author) \\ Department of Public Administration \\ Nueva Ecija University of Science and Technology \\ Philippines
}

Received: June 14, 2018 Accepted: June 29, 2018 Online published: July 1, 2018

doi:10.5296/jpag.v8i2.13345 URL: https://doi.org/10.5296/jpag.v8i2.13345

\begin{abstract}
Transparency and accountability are essentials to the operation of governments. They are tools to prevent corruption. The study assessed the observance of the shared principles of transparency and accountability in the local legislative departments of five cities in the province of Nueva Ecija, in the Philippines. It discussed the importance of transparency and accountability in local governance; described the shared commitment to governance principles of accountability and transparency of local legislators, and correlated local legislators commitment to governance principles to legislative performance measured in terms of the number of ordinances and resolutions made. Using the mixed methods of research and Pearson Product Moment Correlation, the study found that: (a) the twin principles of transparency and accountability are necessary for local legislative operations; (b) local legislators observed governance principles of transparency and accountability and; (c) actual observance of transparency and accountability are associated to higher level of legislative performance. The study recommended that observance of transparency and accountability may be strengthened through the use of Information Communications Technology not only to monitor legislative duties but also to better respond to public demands and produce the quality of services commensurate to the value of public money.

\section{Introduction}

Transparency and accountability are essentials to the operation of governments regardless of the type of regimes and territorial boundaries of States (Ackerman, 2004; Listend \&Naurin 2010; Lindberg, 2013). They are seen as complements of policy effectiveness such as when citizens collectively act against power holders who support bad policies or commit inaction
\end{abstract}


despite the presence of urgency to commit action (Gabriel, 2017; Gabriel \& Gutierrez 2017). Transparency is a tool to increase government accountability to the people, especially in a democratic setup. It is the sunlight that disinfects" the dark corridors of power" from inefficiency and corrupt practices. When actual adherence is observed, they benefit citizens. These twin principles of good governance are so important that the World Bank (WB, 2008) considers "accountability exchange" and the free flow of information as preconditions for development (Islam, 2016).

The need for actual adherence to transparency and accountability is especially true among governments that are negatively perceived as corrupt. The image of Philippine bureaucracy is negatively appreciated. According to the World Bank Report (Quah, 2017), from 1977 to 1997alone there is an estimated 48 billion dollars siphoned from government coffers towards personal pockets of Philippine government officials. A huge amount which would otherwise allocate for development projects or for social services to benefit the poor but diverted to the selfish aggrandizement of bureaucrats (Briones \& Zosa, 1987). This corrupt practice continuously destroys the integrity and public trust to the public institutions (Brillantes \& Fernandez, 2011; World Bank 2008). Consequently, people in the government are generally and unfairly treated as crooks, slow in the delivery of services, inefficient and corrupt. Making the situation worst is the inadequate citizen's engagement in public affairs and the inherently complex built-in procedures in the public offices which slow down the process of transactions in the government. In one study, it was found that Southeast Asia performed poorly in the observance of good governance principles (World Bank, 2006)." The finding is similar to the case of Malaysia wherein lack of transparency and accountability is perceived as a hindrance to economic growth. Accordingto Hira, Murillo, and Kim (2016), developing countries in general, lack or underdeveloped in terms of accountability and transparency ranging from property rights and independent judiciaries.

Transparency and accountability are linked to reform efforts against corruption. Many laws in the Philippines are passed by Philippine Congress to address the issue of corruption. The 1987 Philippine Constitution for instance, devoted an entire article to serve as guidelines for public officials and employees in the execution of their public duties (Bernas, J, G., 1996). The Code of Conduct and Ethical Standards for Public Officials and Employees (Republic Act 6713) is a codification of the standard of behaviors that public personnel should observe in the performance of duties. The Department Order No. 38-20016, created the Presidential Commission on Good Government (PCGG) assigned to get back the alleged ill-gotten wealth of former President Ferdinand Marcos. Unfortunately, these attempts bear no substantial results due to: lack of political will on the part of the leader and agency assigned to implement conflicting laws on corruption, judicial inefficiency, low salaries of government employees, weak citizenship, absence of role model, punitive nature of anti-corrupt policies and lack of reform priorities and inadequate citizens engagement (Brillantes \& Fernandez, 2011; Carino \& Alfiler, 1986; Quah, 2010; Reyes, 1994; and Reyes 1994). According to Carino and Alfiler (1986), majority of anti-corruption laws penalize rather than prevent the commission of corrupt acts. They argued that effective anti-corruption measures must contain both a system of punishing offenders and a built-in mechanism for prevention coupled with 
public support at the agency level generated from the trust to public institutions enough to warrant citizen's active engagement in anti-corruption programs. If trust therefore is the important ingredient to citizens active engagements to curb corruption and the practice of transparency and accountability builds citizens trust in its government, it follows that these governance principles also serve as inputs that will link reform efforts to prevent corruption and tangible outcomes in the agency level. If this is correct, then public administration must be proactive in the fight to eliminate corruption and unethical behavior. And to improve the overall public image, observance of transparency and accountability is a necessary component (Henson, 2016).

However, despite its importance in governance, there is a dearth in the number of literature on transparency and accountability practices in the local context. Many of the studies are based on western experiences, theories, and practices. This study would try to add on to the existing body of knowledge on the topic. It also aimed to countercheck the presence or absence of the theory-practice gap in public administration prevalent in the findings of prominent scholars and Professors Brillantes and Haque. The incongruence of theory and practice in the field of public administration has been the focus of debates in the last decades, thus, the study has academic value.

The study assessed the observance of the shared principles of transparency and accountability in the city governments in the province of Nueva Ecija, Philippines. The subject of inquiry are the legislative branches of five city governments and links its observance to the legislative chamber performance. The study has three main parts. One is the introduction that establishes the importance of transparency and accountability in local governments. The second part deals on the research methodology employed to gather and analyze the data and the last part deals on the interpretation of gathered data and its implications to the practice of public administration.

\section{Objectives of the Study}

The study measured the organizational effectiveness of local City Councils of the component cities of Nueva Ecija, Philippines. Five City Councils and 55 councilors were the respondents of the study. The variables measured their commitment to good governance principles of transparency and accountability. There were three specific objectives of the study, namely;

1) To discuss the importance of transparency and accountability in local governance;

2) To describe the shared commitment to governance principles of accountability and transparency of local legislators;

3) To correlate the local legislators shared commitment to governance principles of transparency and accountability to legislative performance;

\section{Study Local}

The study local consists of five cities in the province of Nueva Ecija in the Philippines. The subject of inquiry is the local legislative body and its observance of the principles of transparency and accountability as well as its possible influence on legislative performance. It 
is a part of a larger study on organizational performance and effectiveness that the authors written and undertaken sometime in 2016. The following information regarding the respondent city legislators elected during the years 2007-2013 are pertinent to the study,to wit;

Table 1. Pertinent Information on Study Locale

\begin{tabular}{lllll}
\hline Name of City & Land Area(Hectares) & Population & $\begin{array}{l}\text { Income } \\
\text { Class }\end{array}$ & Category \\
\hline 1.Cabanatuan & 28,275 & 302,231 & $1^{\text {st }}$ & Component City \\
\hline 2. Gapan & 16,444 & 101,488 & $4^{\text {th }}$ & Component City \\
\hline 3. Munoz & 16,305 & 75,462 & $4^{\text {th }}$ & Component City \\
\hline 4. Palayan & 10,140 & 37,219 & $5^{\text {th }}$ & Component City \\
\hline 5. San Jose & 18,599 & 129,424 & $3^{\text {rd }}$ & Component City \\
\hline
\end{tabular}

PSA Active Stats.nap.psa.gov.ph (2013)

Meantime, to link the legislative performance to the observance of transparency and accountability, the table below shows the legislative outputs of the five city councils in terms of ordinances and resolutions made during the period covered by the study:

Table 2. Summary Table of Local Legislative Output

(2007-2013)

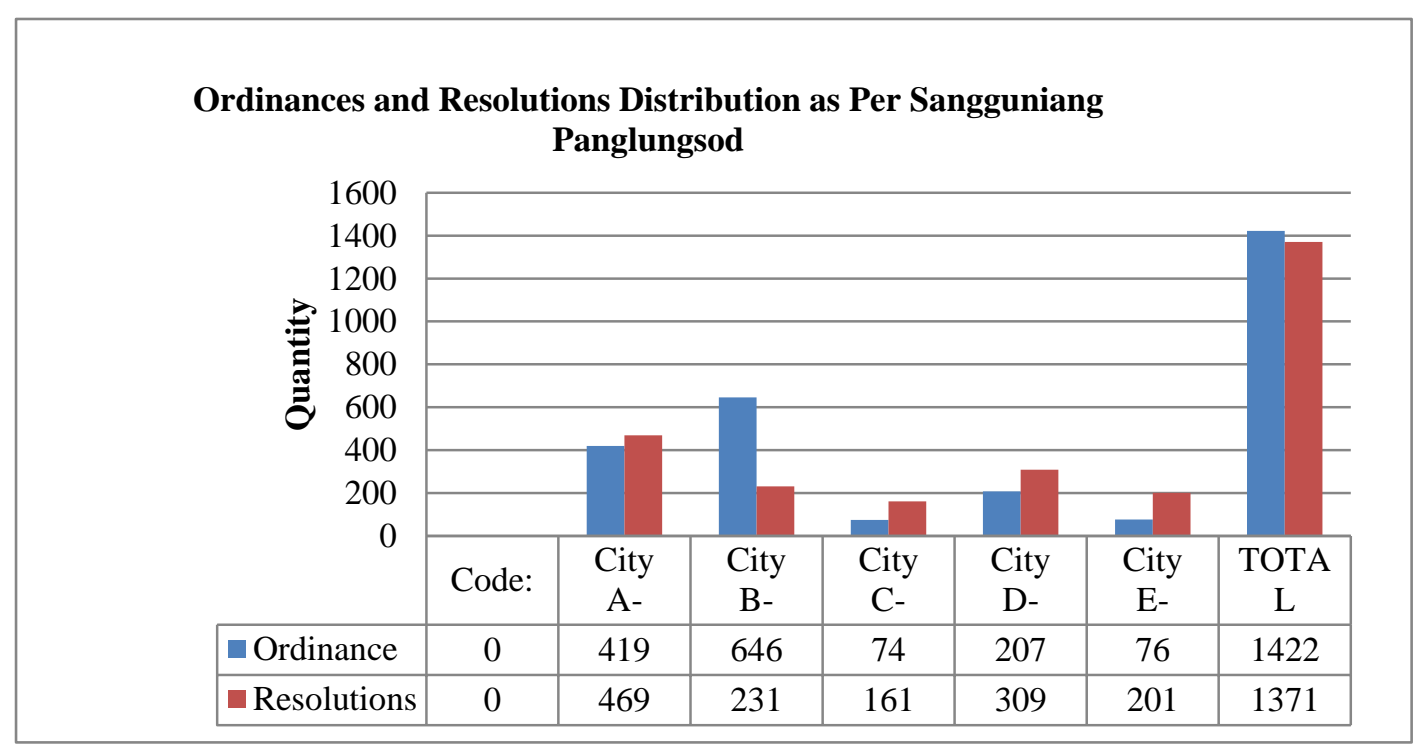

Legend: A=Cabanatuan City; $B=$ San Jose City; $C=$ Palayan City; $D=$ Science City of Munoz; $\mathrm{E}=$ Gapan City

The data above was gathered from actual research in the area.

The local legislative council performance was measured through the number of policies made. It is one of the three branches of government in charge of law making. It is also the branch of government drafting and approving the budget for the Local Government Unit (LGU) in a given fiscal year (LGC, 1991). The legislative outputs could either be in the form of ordinances or resolutions (Villaluz, 2004). 
The table above shows the legislative output of the respondent City Councils in terms of ordinances made. The ordinance is defined as a policy implemented and passed by the local legislative body. It was implementable within the political jurisdictions of the seating legislature. An ordinance has the character of permanence and can only be amended by the same local legislative body. City B had the highest number of ordinances, with646 deliberated and approved during the years 2007-2013. While City $\mathrm{C}$ has the lowest number of legislative outputs. Only 74 ordinances are passed within six years. City A has produced 29.46 percent of the ordinances produced by all cities in six years. The greater percentage was produced by City B with 45 percent of the overall ordinances produced by the five city councils in six years. The lowest percentage of ordinance produced by City $\mathrm{C}$ with only 0.5 percent of the total ordinances produced and passed in the entire province.

Another vital outcome of the local city council operation was the resolution. It is defined as the expression of feeling, support or position of a local legislative body on a certain issue, phenomenon or event. It was based on the recorded minutes of the deliberation of the members of the parliamentary body. As the table shows the city council with the highest number of resolutions made was City A, while the lowest number of passed resolution was City $\mathrm{C}$ with only 161 resolutions in six years.

\section{Methodology}

The study is a mixture of qualitative descriptive and quantitative research methods. The description of the legislators' observance of the principles of transparency and accountability is measured using frequency scaling. The data were gathered using survey, and the questionnaire forms were distributed among 55 members of the five city councils. The answers solicited were subjected to further informal interviews and follow up questions as the need arises. The data on file in the legislative chambers were also used to triangulate responses and interview results. There were 55 participants in the study. Each of the legislative body was represented by 11local legislators, elected and served during the year 2007 to 2013. Cross-references were also used to strengthen theoretical grounding. The data were analyzed using correlation statistics. The influence or relationship between observance of governance principles of accountability and transparency and number of resolutions and ordinances were analyzed using Pearson Product Moment Correlation to link good governance principles to performance. After the internal validity and reliability of the instrument have been ascertained and informed consent granted, the instruments were distributed, and with 90\% retrieval rates, the data were gathered and analyzed. Each of the questionnaire required five to 10 minutes to fill out. The relationship between legislative body outputs and observance of governance principles determined the link between observance of principles and legislative performance.

\section{Result and Discussion}

\subsection{Description of the Observance of Transparency in the Local Legislative Operation}

It is a dictum that government officials are like goldfish in a goldfish bowl (Nigro \&Nigro, 1997). How they execute, their functions must be seen by the citizens. In other jurisdictions, 
transparency is observed not only by public organizations but also of private corporations dealing with government functionaries leading to "sunshine legislation"(Hill,1997). The term transparency is defined as a concept ensuring access to accurate and important information on the activities of the organization by people whether insiders or outsiders(Ingrams, 2016). It has three forms: transparency can be passive,proactive or forced. In many studies on transparency, it is linked to accountability as signified by the conceptual relationship between the two principles; thus, the greater window of transparency creates a higher degree of accountability on the part of government officials. The Table 3shows the transparency rating of the city councils, to wit;

Table 3. Transparency

\begin{tabular}{|c|c|c|c|c|c|c|c|c|c|c|c|c|}
\hline \multirow{2}{*}{ 3. Transparency } & \multicolumn{2}{|c|}{ City A } & \multicolumn{2}{|c|}{ City B } & \multicolumn{2}{|c|}{ City C } & \multicolumn{2}{|c|}{ City D } & \multicolumn{2}{|c|}{ City E } & \multicolumn{2}{|l|}{ Overall } \\
\hline & WM & $\mathrm{AR}$ & WM & $\mathrm{AR}$ & WM & AR & WM & AR & WM & $\mathrm{AR}$ & $\begin{array}{l}\text { Weighted } \\
\text { Mean }\end{array}$ & $\begin{array}{l}\text { Adjectival } \\
\text { Rating }\end{array}$ \\
\hline $\begin{array}{l}\text { 1.On time } \\
\text { submission of } \\
\text { office financial } \\
\text { report }\end{array}$ & 2.44 & $\mathrm{R}$ & 3.56 & $\mathrm{VO}$ & 2.9 & $\mathrm{~S}$ & 2.88 & $\mathrm{~S}$ & 2.88 & $\mathrm{~S}$ & 2.94 & Sometimes \\
\hline $\begin{array}{ll}\text { 2.Posting } & \text { of } \\
\text { fiscal } & \\
\text { information } & \text { on } \\
\text { website } & \\
\end{array}$ & 2.56 & $\mathrm{R}$ & 3.44 & $\mathrm{VO}$ & 2.4 & $\mathrm{R}$ & 2.50 & $\mathrm{R}$ & 2.69 & $\mathrm{~S}$ & 2.71 & Sometimes \\
\hline 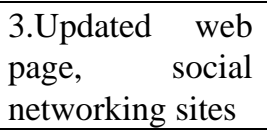 & 2.33 & $\mathrm{R}$ & 3.67 & $\mathrm{VO}$ & 2.2 & $\mathrm{R}$ & 2.75 & $\mathrm{~S}$ & 2.88 & $\mathrm{~S}$ & 2.77 & Sometimes \\
\hline Average & 2.44 & $\mathrm{R}$ & 3.56 & $\mathrm{VO}$ & 2.51 & $S$ & 2.71 & $S$ & 2.82 & $\mathrm{~S}$ & 2.81 & Sometimes \\
\hline
\end{tabular}

As shown in the Table 3, City A has the lowest adjectival rating on transparency. Meanwhile, City $\mathrm{B}$ has the highest rating given to transparency principle with a weighted mean average of 3.56 verbally described as very often observed. The finding is significant considering that lack of public trust is correlated to lack of government transparency. As the Table 3 shows, the common practice in all legislative councils studied is to observe transparency. Meantime, the construct on time submission of report, posting and webpage presence accessible to citizens of the city are observed by City B with the highest average on transparency practice of 3.56 .

\subsection{Description of the Observance of Accountability in Local Legislative Operation}

Accountability is constitutionally guaranteed. It is the reason behind the exercise of political power(Sender et al.,2008). To heighten the degree of accountability, the exercise of discretion of government official is limited (Victoria, 2012). The concept of accountability implies the duty to act responsibly and to be accountable for one's actions. There are different mechanisms of accountability in public administration they are: money, process, and outcomes. For the study, accountability is measured in terms of outcomes (Graycar,2016,)of the legislative bodies in the form of ordinances and resolutions.

The table below shows the accountability rating of city councils, to wit; 
Table 4. Accountability

\begin{tabular}{|c|c|c|c|c|c|c|c|c|c|c|c|c|}
\hline \multirow{2}{*}{ 3. Accountability } & \multicolumn{2}{|c|}{ City A } & \multicolumn{2}{|c|}{ City B } & \multicolumn{2}{|c|}{ City C } & \multicolumn{2}{|c|}{ City D } & \multicolumn{2}{|c|}{ City E } & \multicolumn{2}{|l|}{ Overall } \\
\hline & WM & AR & WM & AR & WM & AR & WM & AR & WM & AR & $\begin{array}{l}\text { Weighted } \\
\text { Mean }\end{array}$ & $\begin{array}{l}\text { Adjectival } \\
\text { Rating }\end{array}$ \\
\hline $\begin{array}{l}\text { 4. Posting of } \\
\text { legislative } \\
\text { process/procedure. }\end{array}$ & 2.78 & $\mathrm{~S}$ & 3.56 & $\mathrm{VO}$ & 2.2 & $\mathrm{R}$ & 2.88 & $\mathrm{~S}$ & 3.00 & $\mathrm{~S}$ & 2.89 & Sometimes \\
\hline $\begin{array}{l}5 . \text { Observance of } \\
\text { internal rules and } \\
\text { procedures. }\end{array}$ & 3.11 & $\mathrm{~S}$ & 3.67 & $\mathrm{VO}$ & 3.9 & $\mathrm{VO}$ & 3.62 & $\mathrm{VO}$ & 3.12 & $\mathrm{~S}$ & 3.49 & $\begin{array}{l}\text { Very } \\
\text { Often }\end{array}$ \\
\hline $\begin{array}{l}\text { 6..Support to } \\
\text { suspension of } \\
\text { erring barangay } \\
\text { official in the city. }\end{array}$ & 3.22 & $\mathrm{~S}$ & 3.67 & VO & 3.6 & VO & 3.75 & VO & 3.06 & $\mathrm{~S}$ & & Sometimes \\
\hline $\begin{array}{l}\text { 7.. Support to } \\
\text { "recall" election . }\end{array}$ & 3.22 & $S$ & 3.11 & $S$ & 1.9 & $\mathrm{R}$ & 3.12 & $S$ & 2.75 & $S$ & 2.81 & Sometimes \\
\hline Average & 3.08 & $\mathrm{~S}$ & 3.50 & $\mathrm{VO}$ & 2.90 & $\mathrm{~S}$ & 3.34 & $\mathrm{~S}$ & 2.98 & $\mathrm{~S}$ & 3.06 & Sometimes \\
\hline $\begin{array}{l}\text { The responden } \\
\text { However, differ } \\
\text { very often by al } \\
\text { This directs the } \\
\text { rules would wa1 } \\
\text { themselves the } \\
\text { different. It is } \\
\text { weighted mean } \\
\text { accountability n } \\
\text { across cities. It } \\
\text { it is the City B } \\
\text { often." }\end{array}$ & aty & per & $\begin{array}{l}\text { ratio } \\
\text { ion } \\
\text { rve } \\
\text { ed a }\end{array}$ & of & $\begin{array}{l}\text { e } 1 \\
\text { pen } \\
\text { l ru } \\
e q\end{array}$ & sla & e b & nch & Besi & es $f$ & $\begin{array}{l}\text { ilure to o } \\
\text { them ass } \\
\text { average re } \\
\text { nction. Th } \\
\text { served. A } \\
\text { rage weig } \\
\text { mong the }\end{array}$ & $\begin{array}{l}\text { metimes". } \\
\text { it is rated } \\
\text { rnal rules. } \\
\text { bserve the } \\
\text { med upon } \\
\text { sponses is } \\
\text { e average } \\
\text { mong the } \\
\text { hted mean } \\
\text { five cities, } \\
\text { d as "very }\end{array}$ \\
\hline
\end{tabular}

\subsection{Correlation between the Local Legislative Commitment to Transparency and} Accountability and Organizational Performance

\subsubsection{Transparency and Legislative Performance}

There were three variables measured to determine the observance of transparency by local legislators, to wit; a) on time submission of the financial report; b) use of the website to disseminate financial information; c) updated email address, social media for feedback and civic engagement.The overall correlation results computed in the study on the significant relationship between transparency variables and legislative performance are as follows:

a) 0.391 not significant at 0.298 and having a degree of little relationship to quantity of ordinance for City A; The cities D and E also showed the same degree of correlation. The cities A D and E yielded significant relationship, although little correlation is recorded between legislative performance and observance of transparency. On the other side, the $\mathrm{r}$-value of cities B and C is 0.719 interpreted as the strong degree of correlation and 0.406 $\mathrm{r}$-value interpreted as moderately significant. Meaning, there is a direct positive correlation 
between observance of transparency principle and legislative output. In theory, citizens' participation in parliamentary operation heightens the government commitment to provide quality service and performance outputs. The more open the window of transparency the higher is the degree of accountability.

\subsubsection{Accountability and Legislative Performance}

The accountability principle was measured using the following constructs: a) posting of legislative procedure, b) observance of internal rules; c) suspension of barangay officials and d) support for recall elections. They are elements of accountability in a parliamentary arrangements operating within a democratic system. Based on data gathered, the following overall $r$ values are arrived at:

Table 5. Summary Table for Accountability

\begin{tabular}{cccc}
\hline City & t-value & $\begin{array}{c}\text { Level of significance }(\mathbf{0 . 0 5}) \\
(\boldsymbol{\rho}-\boldsymbol{v} \boldsymbol{a l u} \boldsymbol{e})\end{array}$ & Interpretation Result \\
\hline $\mathrm{A}$ & 0.323 & 0.396 & Not Significant \\
\hline B & 0.523 & 0.149 & Not Significant \\
\hline C & -0.63 & 0.016 & Significant \\
\hline D & -0.327 & 0.429 & Not Significant \\
\hline E & 0.304 & 0.253 & Not Significant \\
\hline
\end{tabular}

The correlation of accountability principle and quantity of ordinance authored and approved per legislator are both negatively and positively shown. For the council members, posting of procedure and observance of internal rules are negatively correlated to the number of ordinances. The recall elections and support to the suspension of erring barangay officials are strongly correlated to legislative performance. As a whole, cities $\mathrm{A}$, and $\mathrm{E}$ manifested little positive correlation; this implies that among council members of cities $\mathrm{A}$ and $\mathrm{E}$, they perceived accountability as related to the quantity of ordinance produced. Both Cities A and E consider observance of accountability as part of their legislative functions and could influence their legislative outputs by the manner they observed the twin principles of transparency and accountability. Meanwhile, City B shows moderate relationship between the observance of the principle of accountability and legislative performance. It has an $r$ value of 0.523 not significant at 0.149 . The principle of accountability in local governance is proven to affect parliamentary performance. In general, increase accountability pushes the government official to perform better while in office. Good governance principle of accountability works toward effective parliamentary duties (World Bank, 2005). The negative but significant correlation between accountability and legislative performance is recorded in the case of City $\mathrm{C}$ where the observance of higher degree of accountability could be said to influence negatively the output of the city council. The negative correlation implies that inverse relationship is observed between the variables of accountability and legislative output. This requires further study. All the rest of the respondents show not significant correlation.

\section{Conclusion and Recommendations}

The study proved that the five local legislative bodies of component cities in Nueva Ecija observed governance principles of transparency and accountability. But the description generated is "sometimes" which could be deduced as inconsistent to the basic principle that 
government must always observe transparency and accountability. The data also showed the link between observance of governance principles and legislative output. This means that the higher the observance of transparency and accountability, the greater the legislative output within a certain period of time. The City B having the highest degree of performance among legislative bodies showed the interplay between governance principles and practice and local legislature productivity. It is to be noted that more than an individual set of principles, transparency and accountability are organizational norms upon which public trust to the public institution is rebuilt. The development of New Public Administration Model (NPM) demands that delivery of tangible result is the end all of the performance of every government office. But this should not relegate the significance of legislative process where good governance principles may be observed and adhered to. And as the study showed two important principles in public administration that influenced governmental outcomes if not ensure governmental operation under the era of New Public Administration Model where measurement of performance is done through concrete and tangible results of operation.

The findings of the study generated from local context are supported by studies elsewhere in the Southeast Asia where the link between performance and observance of governance principles are established. Transparency, accountability and citizens' participation are proven correlated with improved performance and are proven to minimize corruption in the government. For instance, citizens 'participation in Thailand and Indonesia improved the performance of the local government of Praya Bunlou and mobilized the support of Forum Warga for participatory development (Gabriel, 2017). The practice of transparency is also found to provide benefits such as: (a) higher gross domestic product; (b) lower levels of corruption; (c) long term economic development;(d) involvement in policymaking, and;(e) creation of the trust to the government. Transparency and accountability are effective tools against corruption. The emergence of ICT in public administration bring about new and effective way of minimizing corruption in the delivery of public service and a dependable ally to respond to the demands of accountability and transparency in public setting(Orelli,2016). It is also a tool to strengthen democracy in the local level where citizens could participate fully in governance (Bawan et al.2017).

The local legislative body is a subpart of an integrated whole and interlinked to the bigger system of Local Government Unit (LGU) operations. Its malfunction delays crucial development program of the entire LGU system. On the contrary, its effective and efficient performance of functions may hasten the realization of local development goals.

Finally, ordinances are local laws that provide legitimacy to the use of public funds. They are the outputs of the observance of transparency and accountability in legislative operation. Apropos, adequate performance of legislative functions and the principles of transparency and accountability offer life and spirit to the otherwise barren constitutional principle that "public office is a public trust.

Given the findings of the study, the following recommendations are at this moment submitted:

(a) For the DILG to devise a mechanism to track the whereabouts of local legislators when 
not in session. Transparency dictates that they must serve by the number of hours required by their office.

(b) The local legislative body to require observance of the twin principles of transparency and accountability through mechanisms and structures that would ensure transparency and accountability in operation. The use of ICT is a wise option. The application of ICT may further the transparency and accountability principles in the arena of policymaking.

(c) Create a local legislative body quality assurance team. This ensures the quality of ordinances and resolutions made.

(d) The study may be replicated in some municipalities using quality ordinances which could be linked to transparency and accountability in legislative advocacy.

(e) Finally, the study provides the area for future research where performance measurement and its applicability to local context are employed in the organizational practice thereby minimizing the theory and practice gap.

\section{References}

Ackerman, J. (2004).Co-governance for accountability: Beyond Exit and voice. World Development, 32, 447-63. https://doi.org/10.1016/j.worlddev.2003.06.015

Alfiler, M. C. P. (1985). Corruption Control Measures in the Phillippines: 1979-1982. PhilippineJournal of Public Administration, XXIX(2), (April 1985).

Aniga, F. C. (2014). Clients Experiences onthe Frontline Servicesof SLSU-TOMAS OPPUS. Journal of Educational and Human Resource Development, 2, 141-154.

Bawan, O. M., Marcos, M. I. P., \& Gabriel, A. G. (2017) E-Participation of Selected Professional Students in the Governance of Cabanatuan City in the Philippines. Open Journal of Social Sciences, 5, 126-139. https://doi.org/10.4236/jss.2017.512010

Bernas, J. G. (1996). The 1987 constitution of the Republic of the Philippines: A commentary. Rex Bookstore, Inc.

Brillantes, A. B., \& Fernandez, M. T. F. T. (2011). Restoring trust and building integrity in government: Issues and concerns in the Philippines and areas for reform. International Public Management Review, 12(2), 55-80.

Brillantes, A. B., \& Fernandez, M. T. (2013). Theory and Practice of Public Administration in the Philippines: Concerns about an Identity Crisis. Asian Journal of Political Science, 21(1). https://doi.org/10.1080/02185377.2013.793562

Briones, L. M., \& Zosa, A. R. (1987). Regulating Public Enterprises and the Privatization Policy of the Philippines. World Bul, 3, 13.

Carino, L. V., \& Alfiler, M. C. P. (1986). Bureaucratic corruption in Asia--causes, consequences, and controls. JMC Press. 


\section{Mll Macrothink}

Journal of Public Administration and Governance ISSN 2161-7104 2018, Vol. 8, No. 2

Gabriel, A. G. (2017). Transparency and accountability in local government: levels of commitment of municipal councilors in Bongabon in the Philippines. Asia Pacific Journal of Public Administration, 39(3), 217-223. https://doi.org/10.1080/23276665.2017.1368902

Gabriel, A. G., \& Gutierrez, M. P. (2017). Praxis in Local Legislative Governance: Measure of Organizational Effectiveness of the Component Cities in Nueva Ecija, Philippines. Asia Pacific Journal of Multidisciplinary Research, 5(2).

Gabriel, A. G. (2013). Study Guide in Political Science. Nueva Ecija University of Science and Technology Printing Press Cabanatuan City Philippines.

Graycar, A. (2016) Accountability Mechanisms. In: Farazmand A. (eds) Global Encyclopedia of Public Administration, Public Policy, and Governance. Springer, Cham.

Haque, S. (2007). Theory and Practice in Public administration in Southeast sia:Traditions, Directions, and Impacts. International Journal of Public Administration, 30, 1297-1326. https://doi.org/10.1080/01900690701229434

Hill, M. (1997).” The Policy Process: A Reader”: 9780136169475: Routledge Publisher.

Henson, C. R. (2018). Measuring Leader Effectiveness. In: Farazmand A. (eds) Global Encyclopedia of Public Administration, Public Policy, and Governance. Springer, Cham. https://doi.org/10.1007/978-3-319-31816-5_2822-1

Hira, A., Murillo, M., \& Kim, A. (2016) Globalization and Corruption. In: Farazmand A. (eds) Global Encyclopedia of Public Administration, Public Policy, and Governance. springer, Cham. https://doi.org/10.1007/978-3-319-31816-5_3152-1

Integrated Center for Municipal Development. (2010). “International Experience in PerformanceMeasurement,"OntarioCanada"004Municipal Retrieved from www.researchgate.net/...Convincing_Legislators_with_Performance_Measurement

Ingrams, A. (2016). Transparency. In: Farazmand A. (eds) Global Encyclopedia of Public Administration, Public Policy, and Governance. Springer, Cham. https://doi.org/10.1007/978-3-319-31816-5_2256-1

Islam, M. S. (2018). Good Governance. In: Farazmand A. (eds) Global Encyclopedia of Public Administration, Public Policy, and Governance. Springer, Cham. https://doi.org/10.1007/978-3-319-31816-5_1747-1

Lindberg, S. I. (2013). Mapping accountability :core concept and subtypes. International Review of Administrative Sciences, 79, 202-226. https://doi.org/10.1177/0020852313477761

Linstend, \&Naurin, M. (2010). Transparency is not enough: Making transparency effective in preventing corruption .International Political Science Review, 31, 301-332.

Municipal Association of Victoria. (2012). "Performance and Accountability - Reflections from Audits" Retrieved from (" www.audit.vic.gov.au/ presentations/ performance -and accountability-MAV.pdf. 


\section{Macrothink}

Journal of Public Administration and Governance

ISSN 2161-7104

2018, Vol. 8, No. 2

Nigro, F., \& Nigro, L. (1997)Modern Public Administration https://books.google.com >

Orelli, R. L. (2016). E-Government, Accountability, and Performance. In: Farazmand A. (eds) Global Encyclopedia of Public Administration, Public Policy, and Governance. Springer, Cham. https://doi.org/10.1007/978-3-319-31816-5_2322-1

Osborne, D., \& Gaebler, T. (1992) How entrepreneurial spirit is transforming the public sector." Reading MA Addison Wesley 1992 https://www.jstor.org/

Philippine Statistics Authority. (2011) nap.psa.gov.ph/activestats /psychoactive Parliamentary Center and the World Bank "Parliament that works: A Conceptual framework for parliamentary performance, 2005.Retrieved. July 5, 2014, from www1.worldbank.org/publicsector

Quah, J. S. (2010). Curbing corruption in the Philippines: is this an impossible dream? Philippine Journal of Public Administration, 54(1-2), 1-43.

Quah, J. S. (2004). Best Practices for Curbing Corruption in Asia. The Governance Brief.Issue 11-2004.

RA 7160 Local Government Code of 1991. Retrieved.. 5 July 2014from ppp.gov..ph/wp-July 2014

Reyes, D. R. (1994) REINVENTING Government and Bureaucracy in the Philippines: Old Themes and a new image? Philippine Journal of Public Administration, XXXVIII(2) (April 1994).

Sender, Y., Boris, Y., \& Berthet, R. (2008). "Local GovernmentDiscretion and Accountability: A Diagnostic Framework for Local Governance" retrieved 5 July 2014 from site resources.worldbank.org/.../...

Villaluz, E. (2004). " Local Legislators Toolkit." Local Government Academy of the

The Philippines, LGA Building Pasig City Philippines

World Bank. (2017). Governance and the Law. World Development Report. Washington, DC: World Bank.

World Bank. (2008). Management strategy for local government to Strengthen Transparency in Local Governance,United Nations Office on Governance, Global Governance Assessment.https://www.odi.org/projects/1286-world-governance-assessment Zedi.1997 International Services. 1997

World Bank. (2008). "Evolution Concept of Good Governance Audits Impact on Human Rights “Doctoral Workshop on Development and International Organizations" Stockholm Sweden, May 29,30, 2010/ Nicole Maldonado University of Bonn Law School Germany Retrieved from www2.wawick 1.uk/fac/soc/pain/csgr/.../maldorado_nicole_paper_finel 
World Bank. (2006). Management strategy for local government to Strengthen Transparency in Local Governance, United Nations Office on Governance, Global Governance Assessment., uel: https://goo.gl/NK2sm4

\section{Copyright Disclaimer}

Copyright for this article is retained by the author(s), with first publication rights granted to the journal.

This is an open-access article distributed under the terms and conditions of the Creative Commons Attribution license (http://creativecommons.org/licenses/by/4.0/). 